\title{
Authigenic or detrital origin of pyrrhotite in sediments?: Resolving a paleomagnetic conundrum
}

\author{
Chorng-Shern Horng ${ }^{a, *}$, Andrew P. Roberts ${ }^{b}$ \\ ${ }^{a}$ Institute of Earth Sciences, Academia Sinica, P.O. Box 1-55, Nankang, Taipei, Taiwan, ROC \\ ${ }^{\mathrm{b}}$ National Oceanography Centre, University of Southampton, European Way, Southampton SO14 3ZH, U.K.
}

Received 25 May 2005; received in revised form 29 October 2005; accepted 7 November 2005

Available online 15 December 2005

Editor: V. Courtillot

\begin{abstract}
Monoclinic pyrrhotite $\left(\mathrm{Fe}_{7} \mathrm{~S}_{8}\right)$ is widely claimed to carry magnetizations acquired during early diagenesis in anoxic sedimentary environments. In contrast, geochemical literature indicates that pyrrhotite formation is extremely slow below $180{ }^{\circ} \mathrm{C}$, which makes it a highly unlikely carrier of early diagenetic remanences in sediments. This view is confirmed by the occurrence of late diagenetic $\mathrm{Fe}_{7} \mathrm{~S}_{8}$ in ancient sediments and the general lack of $\mathrm{Fe}_{7} \mathrm{~S}_{8}$ in modern sediments. Horng et al. [C.S. Horng, M. Torii, K.S. Shea, S.J. Kao, Inconsistent magnetic polarities between greigite- and pyrrhotite/magnetite-bearing marine sediments from the Tsailiao-chi section, southwestern Taiwan, Earth Planet. Sci. Lett. 164 (1998) 467-481.] documented the presence of $\mathrm{Fe}_{7} \mathrm{~S}_{8}$ that carries a magnetic signal indistinguishable from that of detrital magnetite in Pleistocene marine sediments from Taiwan. We tested the possibility that the $\mathrm{Fe}_{7} \mathrm{~S}_{8}$ could have a detrital origin by conducting a source-to-sink study and found $\mathrm{Fe}_{7} \mathrm{~S}_{8}$ in metamorphic rocks of the Taiwan Central Range and in material eroded from these rocks in the transportation pathway and in the depositional sink. This confirms that the $\mathrm{Fe}_{7} \mathrm{~S}_{8}$ has a detrital origin. Rapid transportation from source to sink (e.g., by typhoon-associated flood events) probably assists preservation of the $\mathrm{Fe}_{7} \mathrm{~S}_{8}$, which might otherwise oxidize during transportation. The widespread occurrence of exhumed metamorphic rocks in orogenic belts around the world makes them a likely source of $\mathrm{Fe}_{7} \mathrm{~S}_{8}$ in marginal sedimentary basins. Detrital $\mathrm{Fe}_{7} \mathrm{~S}_{8}$ should therefore be more routinely considered to be responsible for paleomagnetic records when it is present in sediments with partial metamorphic provenance.
\end{abstract}

(C) 2005 Elsevier B.V. All rights reserved.

Keywords: pyrrhotite; monoclinic; hexagonal; iron sulphide; authigenic; detrital; diagenesis

\section{Introduction}

Pyrrhotite $\left(\mathrm{Fe}_{1-x} \mathrm{~S}\right)$ has a range of compositions $(0<x<0.13)$, crystal structures and magnetic properties; monoclinic pyrrhotite $\left(\mathrm{Fe}_{7} \mathrm{~S}_{8}\right)$ is ferrimagnetic, whereas hexagonal pyrrhotite $\left(\mathrm{Fe}_{9} \mathrm{~S}_{10}\right)$, orthorhombic pyrrhotite $\left(\mathrm{Fe}_{10} \mathrm{~S}_{11}\right)$ and $\mathrm{Fe}_{11} \mathrm{~S}_{12}$ are antiferromagnetic at ambient

\footnotetext{
* Corresponding author. Tel.: +88622783 9910; fax: +88622783 9871.

E-mail address: cshorng@earth.sinica.edu.tw (C.-S. Horng).
}

temperatures [2]. Pyrrhotite can occur as an accessory mineral in igneous, sedimentary and metamorphic rocks, as well as a major mineral in some hydrothermal ore deposits [3], hydrothermally altered sediments [4], and Martian meteorites [5]. Monoclinic pyrrhotite can significantly contribute to the remanent magnetization of its host rock [4-8], so understanding its likely distribution in geological environments is important.

Thermodynamic data suggest that pyrrhotite should not form under normal Eh-pH conditions in reducing diagenetic sedimentary environments [9]. Kinetic data 
indicate that, even under appropriate diagenetic conditions, pyrrhotite formation will be extremely slow below $\sim 180{ }^{\circ} \mathrm{C}[10,11]$. Thus, while it is possible for pyrrhotite to form in sediments, it should not be able to grow fast enough to produce an early diagenetic magnetization. Despite these difficulties, pyrrhotite has been widely claimed to be a remanence carrier in sedimentary rocks (e.g., [1,12-21]). In these studies, there are many instances where pyrrhotite is interpreted to have grown during early diagenesis, although little evidence is usually provided to demonstrate that the pyrrhotite had an authigenic origin.

Monoclinic pyrrhotite has been demonstrated to be an important remanence carrier in Pleistocene sediments from Taiwan $[22,23]$. It was observed that the pyrrhotite gave paleomagnetic directions that were consistent with those of detrital magnetite, whereas greigite-bearing sediments in the same sequence yielded contradictory polarities that were not consistent with independent geochronological constraints $[1,24]$. This observation suggests that the monoclinic pyrrhotite could have a detrital rather than an authigenic origin. A similar study of lower Pliocene sediments from southern Italy also demonstrated that monoclinic pyrrhotite yielded paleomagnetic directions that were consistent with those of magnetite [13]. However, Linssen [13] argued that the pyrrhotite was not detrital in origin since it would oxidize during transportation from source to sink. In order to resolve a longstanding conundrum associated with the origin of magnetizations carried by monoclinic pyrrhotite in sediments, we have carried out a detailed source-to-sink investigation in Taiwan to determine whether the widely observed sedimentary pyrrhotite in Taiwan has an authigenic or detrital origin.

\section{Geological setting and sampling}

The island of Taiwan straddles the plate boundary between the Eurasian plate and the Philippine Sea plate (Fig. 1a). Oblique collision between these two plates has resulted in development of a mountain belt since the late Miocene [25]. Tectonically, Taiwan can be divided into 5 major units. From east to west, these are the Coastal Range, the Longitudinal Valley, the Central Range, the Western Foothills and the Coastal Plain. The Coastal Range represents an accreted portion of the northern Luzon Arc and mainly consists of andesitic lavas and pyroclastics and a thick Plio-Pleistocene sedimentary succession. The Longitudinal Valley represents the suture zone between the continental margin of the Eurasian plate and the Luzon Arc on the
Philippine Sea plate. The Central Range contains a variety of pre-Tertiary metamorphic basement rocks, including schists, marbles, amphibolites, and gneisses. Unconformably overlying the basement is a highly deformed argillite-slate belt that formed as a result of Plio-Pleistocene low-grade regional metamorphism of a thick sequence of Tertiary marine sediments that were altered to form argillites, slates, phyllites, and quartzites. The Western Foothills consist of unmetamorphosed Oligocene to Pleistocene siliciclastic sediments that are deformed into a series of imbricate thrust sheets. The Coastal Plain is covered by relatively flat-lying Quaternary alluvium that is underlain by Plio-Pleistocene marine sediments that were deposited in the foreland basin in western Taiwan.

Pliocene-Holocene sedimentary sequences with thicknesses of up to $5 \mathrm{~km}$ have been deposited in the foreland basin as a result of orogenesis [26]. The foreland basin comprises the Western Foothills, the Coastal Plain and the offshore Taiwan Strait (Fig. 1b). Previous analyses of pyrrhotite-bearing sediments $[1,22,23,27]$ focussed on Pleistocene sequences that crop out in river sections along the margins of the Western Foothills (the Tsengwen-chi (TWC), Tsailiaochi (TLC), and Erhjen-chi (EJC) sections; Fig. 1b; Table 1). In this study, we present results from modern pyrrhotite-bearing sediments taken from box cores in the Taiwan Strait (Fig. 1b). Kaoping-chi River is the biggest river that drains from the Central Range through southern Taiwan. Offshore, the narrow shelf is incised by the Kaoping Canyon, which drains to the floor of the South China Sea. The studied box cores follow a depth progression from inner shelf $(30 \mathrm{~m}$ depth) to continental slope (1507 $\mathrm{m}$ depth) along the margins of Kaoping Canyon (Fig. 1b; Table 1) and were recovered during cruise 346 of $R V$ Ocean Researcher-I in 1993.

The foreland basin represents the long-term depositional sink for sediments eroded from the Taiwan orogen. In order to investigate the possibility that the monoclinic pyrrhotite in these sediments has a detrital origin, we sampled low-grade metamorphic rocks from the Central Range along Southern Cross-island Highway 20 (Fig. 1c; Table 1) [28]. To investigate possible sediment transportation pathways, and to test whether monoclinic pyrrhotite can survive fluvial transportation, we took samples from upstream (RV1), midstream (RV2, RV3) and downstream (RV4, RV5, RV6) localities (Fig. 1b, c; Table 1). These samples include water samples that were taken in $2 l$ plastic bottles (at localities RV1, RV4, RV5 and RV6) during times of high typhoon run-off when the suspended sediment load was 

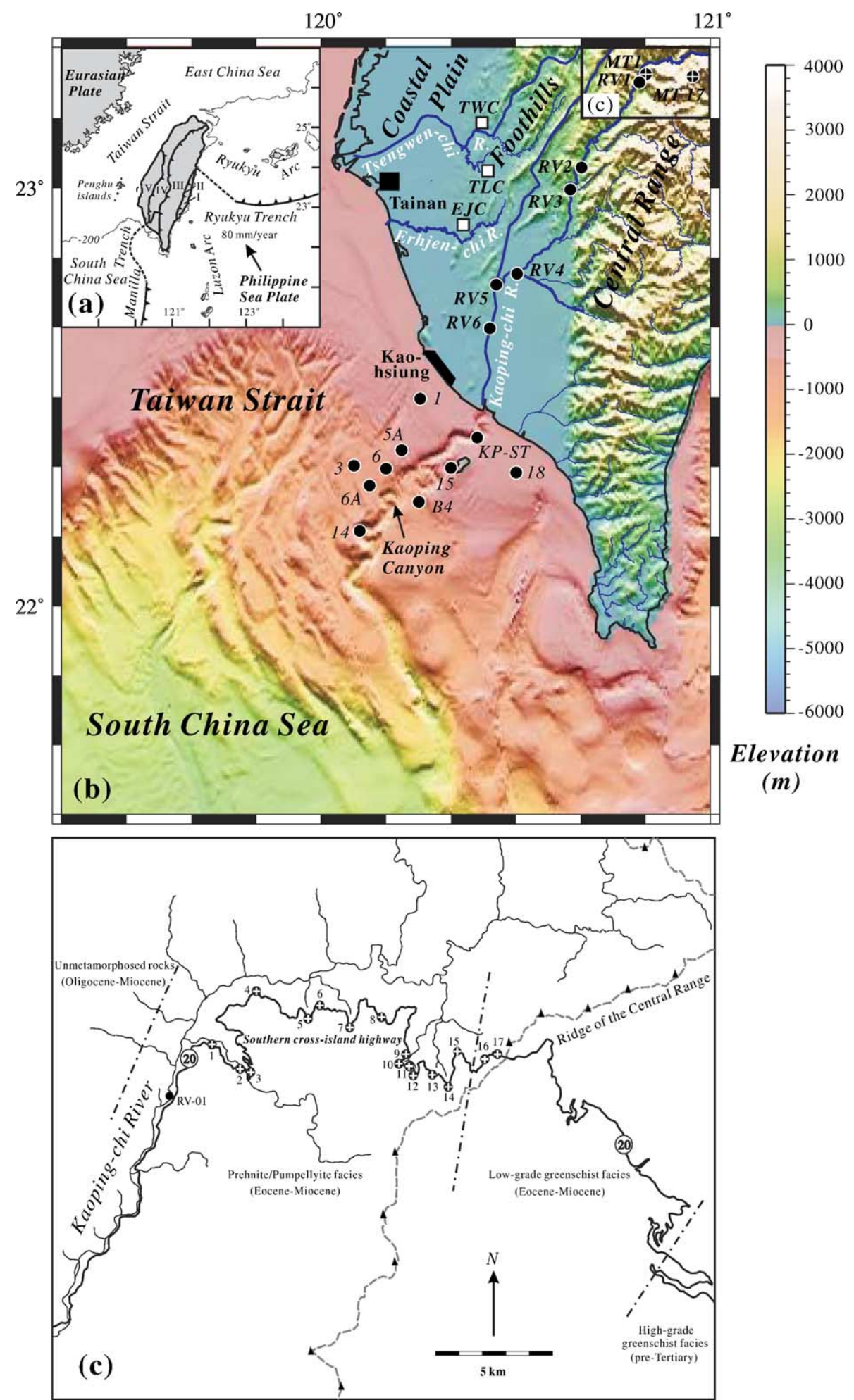

Fig. 1. (a) Tectonic setting of Taiwan and its five geological units: (I) the Coastal Range, (II) the Longitudinal Valley, (III) the Central Range, (IV) the Western Foothills, and (V) the Coastal Plain. (b) The localities from which samples were collected (see Table 1 for details). Three pyrrhotitebearing sections (TWC, TLC and EJC [1,22,23]) that crop out in the Western Foothills are also marked. (c) A more detailed map of the top righthand square in (b) with sites where metamorphic rocks were sampled. The metamorphic grade increases to the east [28]. 
Table 1

Magnetic minerals and hysteresis data for the studied samples at different elevations and locations

\begin{tabular}{|c|c|c|c|c|c|c|}
\hline \multirow[t]{2}{*}{ Sample ID } & \multirow[t]{2}{*}{ Magnetic minerals $^{(1)}$} & \multicolumn{2}{|c|}{ Hysteresis loop ${ }^{(2)}$} & \multirow{2}{*}{$\begin{array}{c}\text { Elevation } \\
\text { (m) }\end{array}$} & \multicolumn{2}{|c|}{ Location } \\
\hline & & $\mathrm{M}_{\mathrm{rs}} / \mathrm{M}_{\mathrm{s}}$ & $\mathrm{H}_{\mathrm{cr}} / \mathrm{H}_{\mathrm{c}}$ & & Long. $\left({ }^{\circ} \mathrm{E}\right)$ & Lat. $\left({ }^{\circ} \mathrm{N}\right)$ \\
\hline \multicolumn{7}{|c|}{ I. Metamorphic terrain, southern cross-island highway } \\
\hline MT-01 & - & Paramagnetic & & 1000 & $120^{\circ} 50.09^{\prime}$ & $2316.19^{\prime}$ \\
\hline MT-02 & - & - & - & 1060 & $120^{\circ} 50.82^{\prime}$ & $2315.63^{\prime}$ \\
\hline MT-03 & - & - & - & 1040 & $120^{\circ} 51.05^{\prime}$ & $2315.53^{\prime}$ \\
\hline MT-04 & - & Paramagnetic & & 1460 & $120^{\circ} 51.20^{\prime}$ & $2317.44^{\prime}$ \\
\hline MT-05 & - & - & - & 1660 & $120^{\circ} 52.51^{\prime}$ & $2316.77^{\prime}$ \\
\hline MT-06 & - & - & - & 1620 & $120^{\circ} 52.78^{\prime}$ & $2317.11^{\prime}$ \\
\hline MT-07 & - & - & - & 1860 & $120^{\circ} 53.54^{\prime}$ & $2316.58^{\prime}$ \\
\hline MT-08 & - & Paramagnetic & & 2040 & $120^{\circ} 54.35^{\prime}$ & $2316.85^{\prime}$ \\
\hline MT-09 & - & - & - & 2320 & $120^{\circ} 54.91^{\prime}$ & $2315.98^{\prime}$ \\
\hline MT-10 & - & - & - & 2340 & $120^{\circ} 54.74^{\prime}$ & $2315.77^{\prime}$ \\
\hline MT-11 & - & - & - & 2340 & $120^{\circ} 55.05^{\prime}$ & $2315.70^{\prime}$ \\
\hline MT-12 & - & - & - & 2360 & $120^{\circ} 55.15^{\prime}$ & $2315.47^{\prime}$ \\
\hline MT-13 & - & Paramagnetic & & 2460 & $120^{\circ} 55.66^{\prime}$ & $2315.47^{\prime}$ \\
\hline MT-14 & $\mathrm{P}$ & 0.69 & 1.19 & 2500 & $120^{\circ} 56.04^{\prime}$ & $2315.20^{\prime}$ \\
\hline MT-15 & - & Paramagnetic & & 2560 & $120^{\circ} 56.22^{\prime}$ & $2316.01^{\prime}$ \\
\hline MT-16 & $\mathrm{P}$ & 0.67 & 1.17 & 2700 & $120^{\circ} 56.94^{\prime}$ & $2315.83^{\prime}$ \\
\hline MT-17 & $\mathrm{P}$ & 0.65 & 1.23 & 2722 & $120^{\circ} 57.28^{\prime}$ & $2315.92^{\prime}$ \\
\hline \multicolumn{7}{|c|}{ II. River suspensions/riverbank deposits, Kaoping-chi } \\
\hline RV-01-S & $\mathrm{P}$ & 0.71 & 1.29 & 720 & $120^{\circ} 49.07^{\prime}$ & $2315.02^{\prime}$ \\
\hline RV-02-D & $\mathrm{P}$ & 0.66 & 1.21 & 300 & $120^{\circ} 40.14^{\prime}$ & $2302.88^{\prime}$ \\
\hline RV-03-D & $\mathrm{P}$ & - & - & 240 & $120^{\circ} 38.39^{\prime}$ & $2259.76^{\prime}$ \\
\hline RV-04-S & $\mathrm{P}$ & - & - & 34 & $120^{\circ} 30.17^{\prime}$ & $2247.69^{\prime}$ \\
\hline RV-05-S & $\mathrm{P}$ & - & - & 32 & $120^{\circ} 27.08^{\prime}$ & $2246.26^{\prime}$ \\
\hline RV-06-S and -D & $\mathrm{P}$ & 0.65 & 1.42 & 14 & $120^{\circ} 26.01^{\prime}$ & $2239.93^{\prime}$ \\
\hline \multicolumn{7}{|c|}{ III. Sediment trap, Kaoping Canyon } \\
\hline KP-ST & $\mathrm{P}, \mathrm{M}$ & 0.26 & 2.01 & -258 & $120^{\circ} 24.08^{\prime}$ & $2224.25^{\prime}$ \\
\hline \multicolumn{7}{|c|}{ IV. Sediments from box cores, Taiwan Strait } \\
\hline OR1-346BC-18 $(0-18 \mathrm{~cm})^{(3)}$ & $\mathrm{P}, \mathrm{M}$ & 0.28 & 2.11 & -30 & $120^{\circ} 30.03^{\prime}$ & $2219.18^{\prime}$ \\
\hline OR1-346BC-01 (0-29 cm) & $\mathrm{P}, \mathrm{M}$ & - & - & -56 & $120^{\circ} 15.23^{\prime}$ & $2229.84^{\prime}$ \\
\hline OR1-346BC-15 (0-39 cm) & $\mathrm{P}, \mathrm{M}$ & 0.17 & 2.42 & -244 & $120^{\circ} 19.96^{\prime}$ & $2219.92^{\prime}$ \\
\hline OR1-346BC-5A $(0-36 \mathrm{~cm})$ & $\mathrm{P}, \mathrm{M}$ & 0.22 & 1.89 & -370 & $120^{\circ} 12.42^{\prime}$ & $2222.45^{\prime}$ \\
\hline OR1-346BC-06 (0-37 cm) & $\mathrm{P}, \mathrm{M}$ & - & - & -620 & $120^{\circ} 10.04^{\prime}$ & $2219.79^{\prime}$ \\
\hline OR1-346BC-B4 $(0-37 \mathrm{~cm})$ & $\mathrm{P}, \mathrm{M}$ & - & - & -712 & $120^{\circ} 15.04^{\prime}$ & $2214.99^{\prime}$ \\
\hline OR1-346BC-03 $(0-32 \mathrm{~cm})$ & $\mathrm{P}, \mathrm{M}$ & 0.15 & 2.77 & -731 & $120^{\circ} 05.07^{\prime}$ & $2220.22^{\prime}$ \\
\hline OR1-346BC-6A $(0-31 \mathrm{~cm})$ & $\mathrm{P}, \mathrm{M}$ & 0.22 & 2.83 & -750 & $120^{\circ} 07.46^{\prime}$ & $2217.36^{\prime}$ \\
\hline OR1-346BC-14 $(0-28 \mathrm{~cm})$ & $\mathrm{P}, \mathrm{M}$ & 0.26 & 1.87 & -1507 & $120^{\circ} 05.94^{\prime}$ & $2210.80^{\prime}$ \\
\hline \multicolumn{7}{|c|}{ V. Pleistocene land sections in the western Foothills } \\
\hline TLC-22 & $\mathrm{P}$ & 0.61 & 1.23 & 30 & $120^{\circ} 24.96^{\prime}$ & $2202.35^{\prime}$ \\
\hline EJC-16 & $\mathrm{P}$ & 0.52 & 1.42 & 35 & $120^{\circ} 22.50^{\prime}$ & $2253.77^{\prime}$ \\
\hline
\end{tabular}

Note: (1) Magnetic mineral identifications are based on X-ray analysis of magnetic extracts. P: pyrrhotite, M: magnetite. Concentrations of magnetic extracts of samples from MT-01 to MT-13 and MT-15 are too low for X-ray analysis. (2) Hysteresis loops were measured for selected bulk samples from the metamorphic terrain and land sections, and for selected magnetic extracts from the river deposits, sediment trap, and box core sediments.

(3) Core interval.

high. In addition, riverbank deposits were sampled at localities RV2, RV3 and RV6 (Fig. 1b; Table 1). Finally, sieved samples from the $<63 \mu \mathrm{m}$ fraction were obtained from a sediment trap located offshore of the mouth of the Kaoping-chi River (KP-ST) for the period from May 31 to June 5, 2004 (Fig. 1b; Table 1).

\section{Methods}

Magnetic extracts were made from all studied materials, including metamorphic rocks from the Central Range, suspended fluvial sediments and riverbank deposits from the Kaoping-chi River, the sediment 
trap from offshore of the mouth of the Kaoping-chi River, and marine sediments from box cores from the Taiwan Strait. The metamorphic rocks were crushed and gently ground into a fine powder, and suspended in water. Magnetic minerals were extracted using a rare earth magnet housed in a plastic sheath. The other samples (riverbank sediments, suspended fluvial sediments, sediment trap and box core sediments) were simply mixed with water (making a slurry for the sediment samples) and the magnetic minerals were extracted as above. Results from all of these materials are presented here. Analyses of pyrrhotite-bearing magnetic extracts from Pleistocene marine sediments exposed in the Western Foothills have already been presented by Horng et al. [1,22,23].

Several types of analysis were made on the magnetic extracts to determine the magnetic mineralogy. X-ray diffraction (XRD) analysis was made using a Rikagu Miniflex table top unit (Cu- $\alpha$ radiation); scans were run from $4^{\circ}$ to $80^{\circ}$ of $2 \theta$. Results are presented after subtraction of the background trend. Magnetic hysteresis loops were measured on selected extracts and bulk rocks using a Princeton Measurements Corporation vibrating sample magnetometer. All samples were magnetically saturated before $500 \mathrm{mT}$, so this was the maximum applied field. Temperature dependence of low-field magnetic susceptibility was measured in an argon atmosphere with an AGICO KLY-3S Kappabridge system and attached CS-3 furnace to determine the Curie temperature(s) of the magnetic mineral(s). Temperature-dependent susceptibility runs were first stopped at $\sim 340{ }^{\circ} \mathrm{C}$ to enable clear detection of the

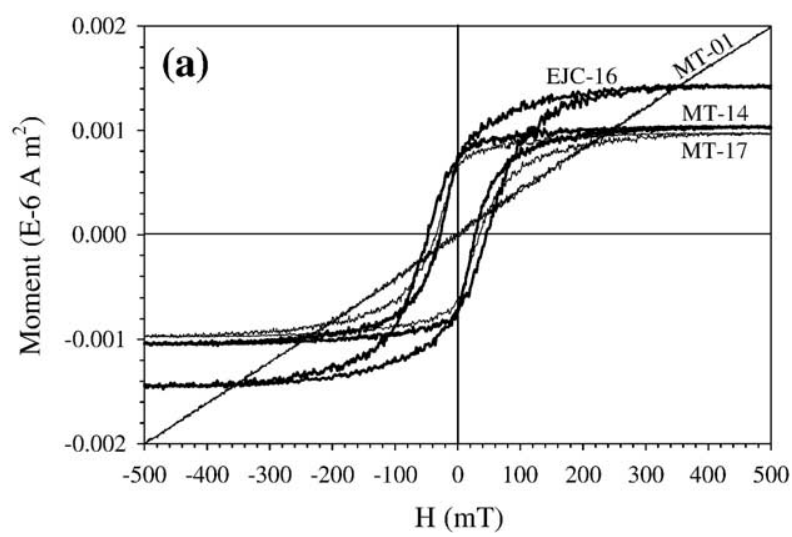

Curie temperature for pyrrhotite at $325{ }^{\circ} \mathrm{C}$ [29] during heating and cooling cycles. When appropriate, higher temperature runs were also made. Direct observations of the magnetic extracts were made using a JEOL JSM6360LV scanning electron microscope (SEM) operated at $15 \mathrm{keV}$ with $18 \mathrm{nA}$ acceleration voltage, and mineral compositions were determined using an Oxford Instruments Ltd. INCA-300 X-ray energy dispersive spectrometer (EDS), respectively. EDS measurements were calibrated using pyrrhotite, greigite and pyrite standards, which allows clear differentiation among these phases on the basis of their distinctive iron to sulphur ratios [e.g., 24,30,31].

\section{Results}

Magnetic extracts from the majority of samples contained sufficient magnetic material for XRD analysis. The only exception was samples MT-01 to MT-13 and MT-15 from the westernmost part of the sampled metamorphic terrain (Fig. 1c), which contain low quantities of magnetic minerals (Table 1). Representative magnetic hysteresis results demonstrate that bulk samples (e.g., MT-01) are magnetically dominated by paramagnetic phases with no measurable concentrations of ferrimagnetic minerals (Fig. 2a). In contrast, the more metamorphosed rocks (samples MT-14, 16 and 17), which crop out at higher elevations in the Central Range (Fig. 1c; Table 1), contain abundant ferrimagnetic phases with open hysteresis loops and single domain-like magnetic properties (Fig. 2a). Hysteresis loops for suspended sediments extracted from the river

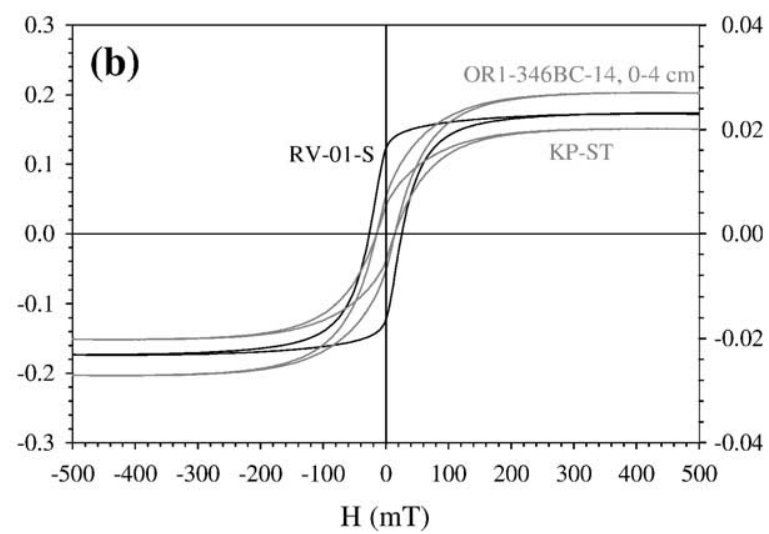

Fig. 2. Hysteresis loops for representative samples from: (a) bulk metamorphic rocks from the Central Range and bulk sedimentary rocks from the EJC section; (b) magnetic extracts from suspended sediments from the upstream section of Kaoping-chi River (RV-01-S), the offshore sediment trap (KP-ST), and uppermost sediments from a box core in Taiwan Strait (OR1-346BC-14, 0-4 cm). Sample details are given in Table 1. Magnetic moments of KP-ST and OR1-346BC-14, 0-4 cm are shown shaded on the right-hand axis. Data from the bulk rocks in (a) are noisier than for the extracts in (b) because of lower concentrations of magnetic minerals in the bulk rocks. All of the loops have been corrected for their paramagnetic slope except for sample MT-01 (which is dominantly paramagnetic and lacks a ferrimagnetic component). 
water (e.g., sample RV-01-S) and for pyrrhotite-bearing Pleistocene sediments from tectonically uplifted marine sections (e.g., sample EJC-16) are consistent with those from the more metamorphosed rocks, while those from the sediment trap and box cores are less square (Fig. $2 b$; Table 1).

XRD data from all samples, except MT-01 to MT-13 and MT-15, indicate variable, but measurable, quantities of monoclinic pyrrhotite (Fig. 3). Monoclinic pyrrhotite is indicated by 5 principal reflections. In particular, the double peak at a $2 \theta$ angle of $\sim 44^{\circ}$ is diagnostic of monoclinic pyrrhotite (hexagonal pyrrhotite only has a single peak in this part of X-ray pattern; [32]). In addition to monoclinic pyrrhotite, variable quantities of quartz and magnetite are present. Magnetite is only identified in the sediment trap and box core samples (Fig. 3).

The fact that the magnetic extracts contain ferrimagnetic monoclinic pyrrhotite is further demonstrated by temperature-dependent susceptibility measurements
(Fig. 4a-c), which all indicate evidence of a maximum unblocking temperature at $\sim 325{ }^{\circ} \mathrm{C}$ [cf. 29]. All thermomagnetic curves indicate the presence of monoclinic pyrrhotite during both heating and cooling (Fig. 4a-c). A second thermomagnetic run up to $650{ }^{\circ} \mathrm{C}$ indicates the presence of magnetite in box core sediments (Curie temperature of $580{ }^{\circ} \mathrm{C}$; Fig. 4d), which is consistent with XRD results that indicate the presence of magnetite in the Taiwan Strait sediments (Fig. 3).

SEM observations and EDS analyses further demonstrate the abundance of pyrrhotite in the magnetic extracts (Fig. 5). Distinct morphologies are not clearly evident in the pyrrhotite-bearing metamorphic samples, apart from occasional platy grains (Fig. 5a), because the rocks were crushed during sample preparation. Similar platy pyrrhotite grains are observed in the river sediments (Fig. 5b). The sediment trap and box core samples contain hexagonal-shaped pyrrhotite particles (Fig. 5c-h). Irregular detrital magnetite grains and spherical magnetite fly-ash particles are

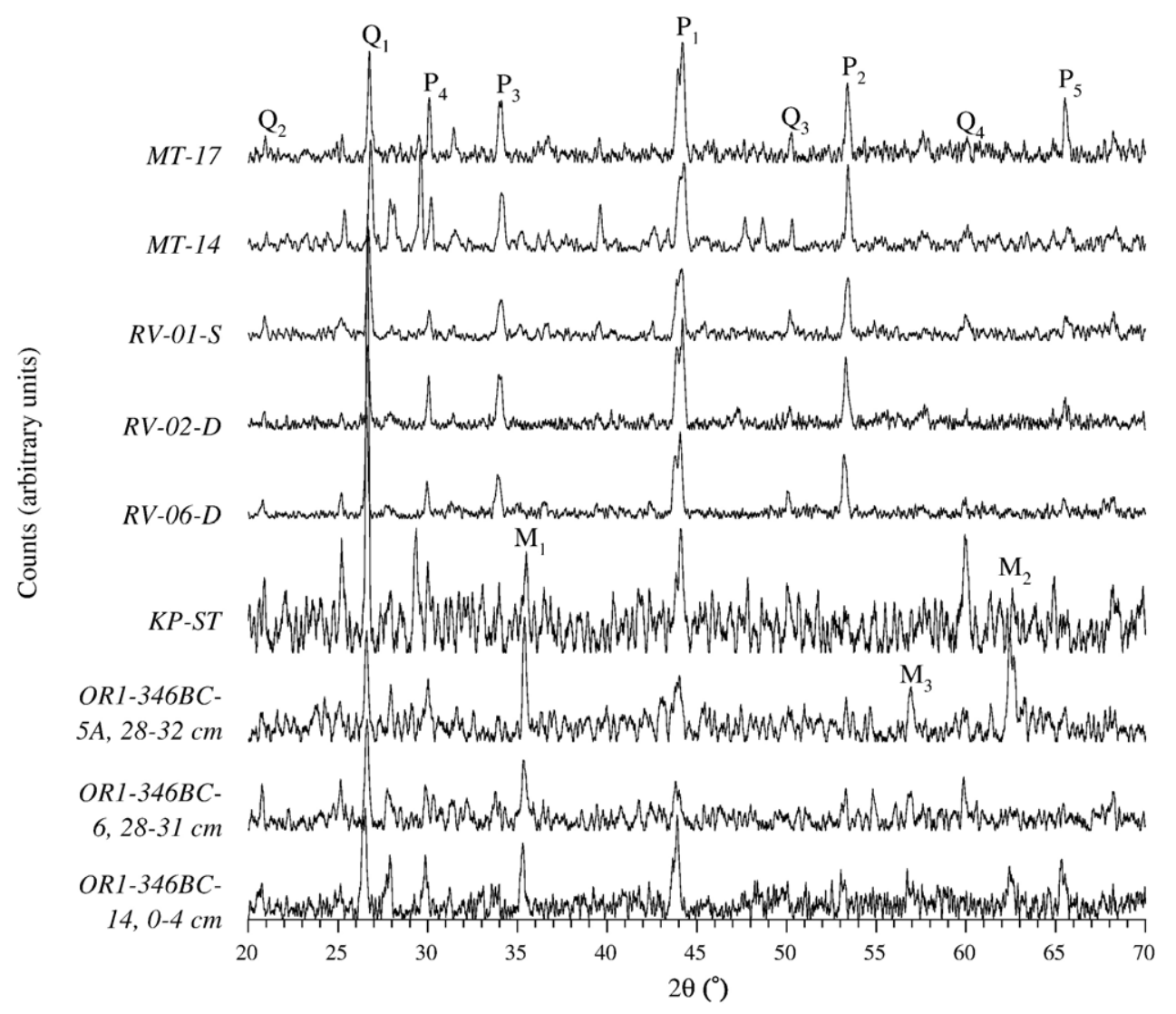

Fig. 3. X-ray diffraction data for magnetic extracts from representative samples from: source (MT) via the transportation pathway (RV and KP-ST) to sink (box cores $5 \mathrm{~A}, 6$ and 14) (sample details are given in Table 1). The 5 main diffraction peaks for monoclinic pyrrhotite are indicated as $\mathrm{P}_{1}-\mathrm{P}_{5}$; $\mathrm{Q}_{1}-\mathrm{Q}_{4}$ are the main quartz peaks, while $\mathrm{M}_{1}-\mathrm{M}_{3}$ are the main magnetite peaks. Monoclinic pyrrhotite is clearly indicated in all samples by the double peak at a $2 \theta$ angle of $\sim 44^{\circ}$ (hexagonal pyrrhotite only has a single peak in this part of X-ray pattern; [32]). 

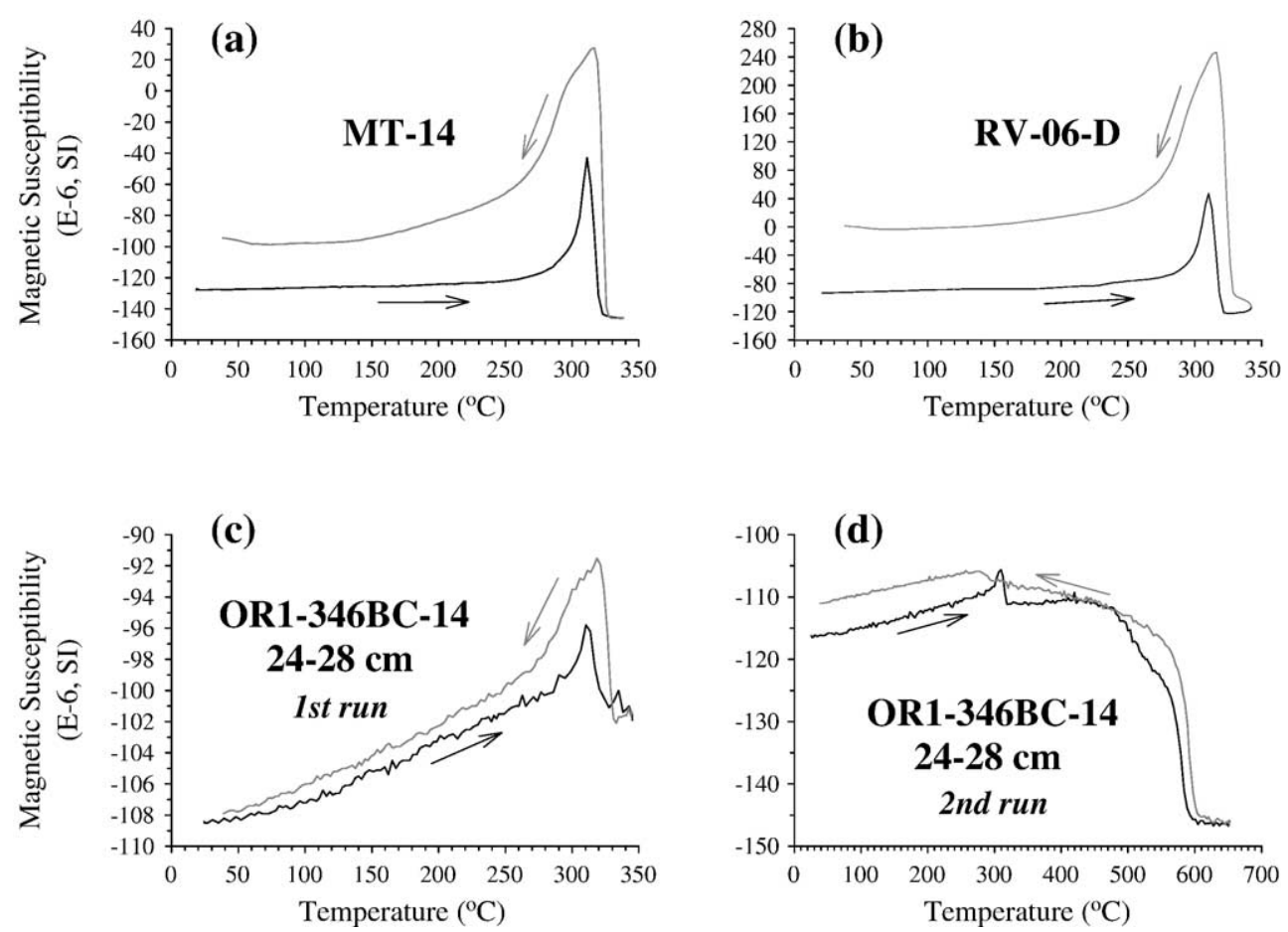

Fig. 4. Temperature-dependent low-field magnetic susceptibility runs for representative magnetic extracts in argon atmosphere. The overall negative magnetic susceptibilities result from the diamagnetism of the plastic and quartz sample holder. (a) Metamorphic rock (MT-14), (b) riverbank sediments (RV-06-D) from the Kaoping-chi River, and (c) box core sediments from the Taiwan Strait (sample OR1-346BC-14, 24-28 cm). Monoclinic pyrrhotite is clearly indicated by the Curie temperature at $\sim 325{ }^{\circ} \mathrm{C}$ on both heating and cooling runs (dark and light curves, respectively). A second thermomagnetic run to higher temperatures for the box core sample, as shown in (d), also indicates the presence of magnetite, which is consistent with X-ray analyses (Fig. 3). Note that pyrrhotite appears to have survived the heating, as indicated by an inflection at around $300{ }^{\circ} \mathrm{C}$ in the cooling curve.

also observed in magnetic extracts from box core samples (Fig. 5i). It is likely that these magnetite particles have an industrial (anthropogenic) origin because there are large coal-burning steel production plants in coastal towns of southwestern Taiwan. Coal combustion produces magnetite spherules as a result of oxidation of framboidal pyrite in coal [e.g., 33]. These particles would have settled out of the atmosphere through the water column and onto the seafloor in the Taiwan Strait. In addition to magnetic extracts, we analysed resin-impregnated polished sections of soft sediments from the box cores and from middle Pleistocene sediments exposed in the Erhjenchi River section (Fig. 1b). Pyrrhotite is clearly present (high electron back-scatter) as grains with irregular cross-section as well as elongated platy grains (Fig. 5j,1). Polished sections from the box core sediments contain clear evidence of graded beds (Fig. 5k). This suggests that a significant proportion of deposition along the Kaoping Shelf and Canyon occurs as a result of distinct gravitational settling events (e.g., turbidites or rapid flood events).

\section{Discussion}

\subsection{Origin of monoclinic pyrrhotite in sediments from Taiwan}

The evidence presented above unambiguously indicates that monoclinic pyrrhotite is ubiquitous in the sedimentary system in southwestern Taiwan and that the pyrrhotite has a detrital rather than an authigenic origin. It should be noted that the area of pyrrhotitebearing low-grade metamorphic rocks within the drainage of the Kaoping-chi River is large (see Fig. 1c), although only a relatively thin section through this unit (corresponding to samples MT14, MT16, and MT17) is accessible along the southern cross-island highway. Our source-to-sink study demonstrates that some low-grade metamorphic rocks from the Central Range contain abundant monoclinic pyrrhotite. Erosion in association with the sampled typhoon event denuded metamorphic rocks in the headwaters of the Kaoping-chi catchment, giving rise to a substantial sediment load in the river, from which measurable concentrations of monoclinic 

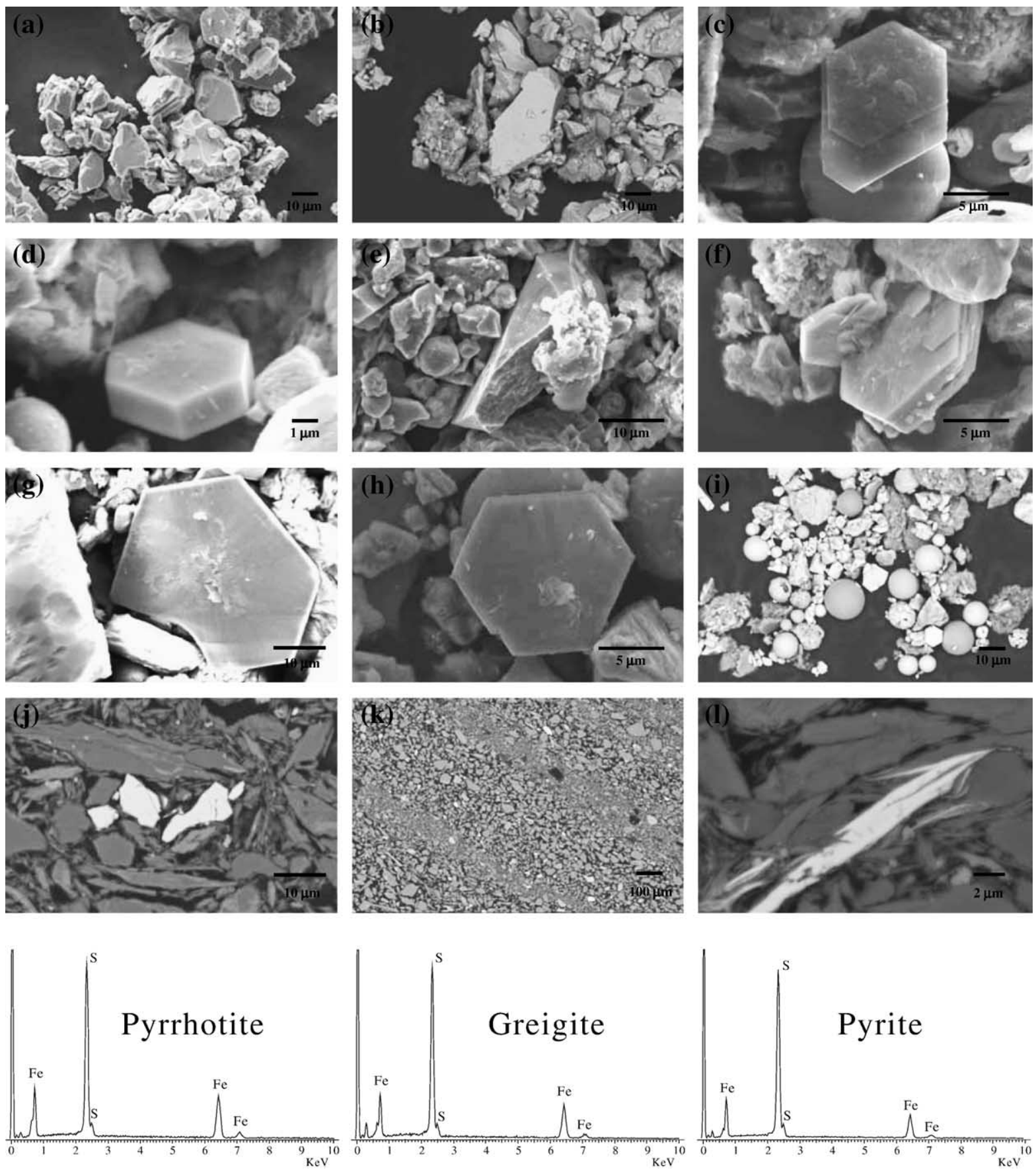

Fig. 5. (a-h) Back-scattered electron images of magnetic extracts containing pyrrhotite with morphologies ranging from irregular to platy hexagonal grains. (a) Metamorphic sample MT-14 after crushing and gentle grinding; (b) riverbank sample RV-06-D; (c, d) the offshore sediment trap KP-ST; (e) box core sample OR1-346BC-5A, 28-32 cm; (f-h) box core sample OR1-346BC-14, 0-4 cm for (f) and (g), and 24-28 cm for (h). (i) Backscattered electron image of spherules from sample OR1-346BC-5A, 16-20 cm. The spherules with higher electron back-scatter consist of magnetite, while the darker ones mainly contain $\mathrm{Fe}, \mathrm{O}$, and variable $\mathrm{Si}$ and $\mathrm{Al}$ contents. (j-1) Back-scattered electron images of resin-impregnated polished sections from a box core and from the EJC section (see Fig. 1b). (j, k) Box core sample OR1-346BC-14, 12-14 cm; (l) middle Pleistocene sample EJC-16 from the EJC section. Grains with high electron back-scatter in (j) and (1) are pyrrhotite grains with variable shape. The graded nature of the box core sediments $(\mathrm{k})$ indicates deposition from distinct gravitational settling events (e.g., turbidites or rapid flood events possibly associated with typhoons). EDS spectra at the bottom of the figure are calibration runs for pyrrhotite, greigite and pyrite standards, respectively; EDS analyses confirm that all observed iron sulphides have a pyrrhotite composition. 
pyrrhotite were extracted. Pyrrhotite is abundant throughout all parts of the sediment transportation pathway and within the depositional sinks en route and all the way out to the Taiwan Strait continental slope. Intense typhoons frequently occur in Taiwan and contribute to the highest denudation rate in the world [34]. Studies of active erosional denudation using ${ }^{10} \mathrm{Be}$ indicate that rivers in southwestern Taiwan have sediment yields that are 70 times the world average, so that the products of extremely rapid erosion are efficiently transported to the sea [35]. The speed with which particles are transported over the relatively short distances from source to sink undoubtedly assists the preservation potential of iron sulphide particles that might otherwise oxidize if they were able to spend long periods of time in oxic environments during transportation from source to sink. The presence of graded beds in box cores (Fig. 5k) from the Kaoping shelf is also consistent with rapid deposition. These beds could be turbidites, but they could simply represent grading associated with gravitational settling after intense sediment discharge events associated with typhoon-induced floods.

While our evidence for the presence of detrital ferrimagnetic monoclinic pyrrhotite in this study is straightforward, the hexagonal shape of the magnetically extracted pyrrhotite grains shown in Fig. 5 might appear to be puzzling. Hexagonal pyrrhotite is not ferrimagnetic, so, if it is present in the source rocks (hexagonal and monoclinic pyrrhotite commonly cooccur in metamorphic rocks [6]), discrete hexagonal pyrrhotite crystals would not be expected to be magnetically extracted. The resolution of this apparent puzzle relates to the fact that monoclinic pyrrhotite can have pseudohexagonal structure [36]. It is therefore likely that the particles shown in Fig. 5 represent pseudohexagonal grains of monoclinic pyrrhotite.

Hysteresis data (Fig. 2) indicate another feature that requires explanation. As would be expected, pyrrhotitebearing metamorphic rocks and pyrrhotite particles extracted from the suspended fluvial sediments both give similarly square hysteresis loops. Likewise, Pleistocene pyrrhotite-bearing marine sediments that crop out in the Western Foothills also produce square hysteresis loops. However, the hysteresis loops for magnetic extracts from the offshore sediment trap and box cores (Fig. 2b) are much less square and do not obviously produce the same magnetic response, which would be expected if the same magnetic material is present in all samples. It should be noted that the magnetic extracts from the sediment trap and the box cores both contain magnetite, which the metamorphic rocks, Pleistocene marine sediments and fluvial sediments do not (Fig. 3). The presence of significant quantities of detrital and anthropogenic magnetite in these samples can explain the different hysteresis characteristics. The detrital magnetite must originate from some source outside the studied Central Range catchment area; it does not enter the sedimentary system until beyond the lower reaches of the Kaoping-chi River. Potential sources of detrital magnetite particles could be either volcanic rocks in the Penghu islands (Fig. 1a) and/or sedimentary and high-grade metamorphic rocks that were eroded by the other major rivers of western Taiwan.

\subsection{Can monoclinic pyrrhotite form during early diagenesis?}

Thermodynamic and kinetic arguments do not favour pyrrhotite formation during early diagenesis. These arguments are well known in the geochemical literature, so why is it that the possibility of early diagenetic pyrrhotite formation seems to be so readily accepted in the paleomagnetic literature? The answer appears to lie in the widespread acceptance of evidence provided by Sweeney and Kaplan [37], who indirectly inferred that hexagonal pyrrhotite formed as a precursor to pyrite in laboratory syntheses at temperatures up to $85{ }^{\circ} \mathrm{C}$. However, more recent syntheses have more carefully identified intermediate products in sulphidization reactions. Hexagonal pyrrhotite has only been identified in syntheses above $180{ }^{\circ} \mathrm{C}$, and monoclinic pyrrhotite has never been observed in these syntheses [10]. Lennie et al. [11] also showed that the kinetics of the transformation of mackinawite to hexagonal pyrrhotite are extremely slow below $\sim 250{ }^{\circ} \mathrm{C}$. All of this evidence provides support for the independent observation that pyrrhotite is unknown in modern anoxic sediments [38] (unless, as is demonstrated here, sources of detrital pyrrhotite exist).

\subsection{Resolution of a paleomagnetic conundrum}

Evidence for a detrital origin of monoclinic pyrrhotite in the sedimentary system of southwestern Taiwan resolves a paleomagnetic conundrum. Paleomagnetic data suggest that the magnetization carried by pyrrhotite in Pleistocene sediments should have been acquired at the same time as detrital magnetite $[1,22,23]$. Some authors have assumed that pyrrhotite will not survive transportation from source to sink [e.g., 13], and, as is relatively commonplace in paleomagnetic studies, the pyrrhotite was assumed to have had an early diagenetic 
origin. Nevertheless, geochemical evidence suggests that formation of monoclinic pyrrhotite is kinetically inhibited at temperatures typical of sedimentary environments during early burial $[10,11]$. This conundrum can be resolved in the present case because rapid transportation from source to sink is aided by the short distances involved and by the extreme nature of frequent, highly erosive typhoon events. Our data conclusively demonstrate that monoclinic pyrrhotite can have a detrital origin, and, given the improbability of rapid authigenic pyrrhotite formation in sediments, its occurrence is far more likely to indicate a detrital rather than an authigenic origin.

\subsection{Can monoclinic pyrrhotite form during later diagenesis?}

While early diagenetic formation of monoclinic pyrrhotite appears to be highly unlikely, there are convincing examples of diagenetic pyrrhotite formation in sediments. The nature of these cases is worth considering because they elucidate the above observations. For example, the only known case of pyrrhotite growth in lacustrine sediments comes from the Paleogene Green River Formation in the western U.S.A. In this setting, sedimentary sulphur geochemistry suggests highly unusual conditions with pore waters that were extremely reducing for long periods of time, which allowed unstable FeS phases to eventually form hexagonal pyrrhotite [39]. The pyrrhotite clearly formed well after significant sediment compaction, so it was not an early diagenetic product. This is consistent with the observation of Rickard et al. [38] that pyrrhotite has been found in ancient sediments, but not in recent sediments. While there are numerous credible reports of monoclinic pyrrhotite in sediments [e.g., 30,40-44], these cases involve rocks that are at least several million years old and they generally involve a tectonically driven fluid migration event that has changed the chemistry of the pore fluids and enabled pyrrhotite formation that remagnetized the host sediment. Presumably these events involved fluids with distinctive chemistry and/or they lasted long enough to overcome kinetic obstacles to formation of monoclinic pyrrhotite. The collective evidence therefore supports the view that it is difficult to form monoclinic pyrrhotite during early diagenesis.

\subsection{Is there a case for mistaken identity?}

Evidence for the presence of monoclinic pyrrhotite in sediments is unequivocal in some published cases.
The requisite evidence includes the double peak at a $2 \theta$ angle of $\sim 44^{\circ}$ in X-ray diffraction data $(\mathrm{Cu}-\alpha$ radiation), which clearly indicates that monoclinic pyrrhotite is responsible for the magnetizations of the respective sediments [e.g., 1,13,17]. However, in many published cases, monoclinic pyrrhotite can only be inferred to be present on the basis of magnetic properties that are suggestive of the presence of pyrrhotite [e.g., 14,18-21]. These magnetic properties include thermal unblocking up to $\sim 325^{\circ} \mathrm{C}$ [29], the presence of a low-temperature magnetic transition at $34 \mathrm{~K}[45,46]$ or relatively high coercivities [47]. While these properties are diagnostic of monoclinic pyrrhotite, they are not unique to pyrrhotite. Several minerals undergo magnetic unblocking between 250 and $350{ }^{\circ} \mathrm{C}$, including greigite [48], titanomagnetite and maghemite [49]. Likewise, potential exists for misidentification of the $34 \mathrm{~K}$ transition during warming of a low-temperature saturation remanence because other minerals undergo magnetic ordering in the $30-40 \mathrm{~K}$ temperature range, including siderite [50] and some titanomagnetites [51,52], although this difficulty can be avoided by cooling a room temperature saturation remanence (which is often not done). Secure identification of monoclinic pyrrhotite therefore requires more documentation than is often provided in paleomagnetic studies. It is therefore highly likely that many claimed occurrences of sedimentary pyrrhotite actually represent occurrences of greigite, which has numerous magnetic properties that are similar to those of pyrrhotite [e.g., 30,48,53], and which is a much more common iron sulphide mineral in reducing diagenetic environments.

\subsection{Should we expect detrital pyrrhotite to be magnetically important in sediments?}

When sediments that were subjected to anoxic diagenesis are later subjected to progressive regional metamorphism, the organic matter in these sediments will thermally mature and produce increasingly reducing conditions [3]. This can lead to the formation of pyrrhotite in metamorphic rocks via breakdown of magnetite or pyrite [3,6,54-57]. Monoclinic pyrrhotite is therefore commonly documented as a carrier of remanent magnetizations in metamorphic [e.g., 6,8,57] and lower crustal rocks [e.g., 7,58].

The abundance of exhumed low-grade metamorphic rocks in subduction zone settings around the Pacific rim and in peri-Alpine basins in northern Europe and the Mediterranean (and elsewhere), and the rapid deposition that occurs in marginal basins in such tectonically 
active settings, suggests that pyrrhotite could be a relatively common detrital magnetic mineral. Rochette [6] argued that monoclinic pyrrhotite will be abundant enough to define a "pyrrhotite isograd" that starts in low-grade metamorphic rocks derived from black shale protoliths and that pyrrhotite will persist in high-grade metamorphic rocks. Potential source rocks for detrital pyrrhotite should therefore be widespread in many regional metamorphic belts. Erosion of such rocks could easily be responsible for occasional reports of monoclinic pyrrhotite in Mediterranean [e.g., 12,13,17] and other peri-Alpine basins [e.g., 21]. Indeed, detrital pyrrhotite has been documented within European loess deposits derived from Alpine fluvio-glacial outwash [59]. On the basis of our results from Taiwan, we therefore suggest that a detrital origin should be more routinely considered for monoclinic pyrrhotite in sediments, especially if evidence points to a syn-depositional acquisition of remanence. More rigorous efforts are also needed to understand the origin of pyrrhotite in sediments to avoid paleomagnetic misinterpretation.

\section{Conclusions}

Monoclinic pyrrhotite contributes to stable magnetizations in Pleistocene to modern sediments from southwestern Taiwan [1]. Our results demonstrate that the magnetizations have a detrital origin and that the pyrrhotite particles are sourced from low-grade metamorphic rocks from the Central Range, Taiwan. In contrast to many paleomagnetic studies of rapidly deposited anoxic sediments in which magnetizations are claimed to be carried by monoclinic pyrrhotite that grew during early diagenesis, geochemical studies indicate that formation of pyrrhotite is not kinetically favoured at such low temperatures $[10,11]$. The conundrum concerning the origin of monoclinic pyrrhotite in sediments is resolved if it has a detrital origin. While many ancient rocks contain pyrrhotite that has authigenically grown during late diagenetic remagnetization events, our work demonstrates that a detrital origin for monoclinic pyrrhotite in sediments is possible and that it is far more likely than an early diagenetic origin. We suggest that detrital monoclinic pyrrhotite is a potentially important remanence carrier in sedimentary basins that receive input from exhumed regional metamorphic belts in orogenic zones around the world.

\section{Acknowledgements}

We thank Kon-Kee Liu and the crew of $R V$ Ocean Researcher- $I$ for arranging the cruise and for recovering the studied box cores, Hui-Ling Lin for providing the sediment trap material, Shuh-Ji Kao for suggesting that we sample the suspended sediment load of rivers during times of high typhoon runoff, Wei-Teh Jiang for discussions about pyrrhotite in the Central Range of Taiwan, Liane Benning for discussions about the kinetics of pyrrhotite formation, Steve Roberts for discussion of mineralogical problems, Zhong Zheng for preparing resin-impregnated polished sections, Yoshi Iizuka for helping with SEM analysis, and Kuo-Hang Chen, ChyiKun Yao and Yi-Chun Chen for field and laboratory assistance. Masayuki Torii and an anonymous reviewer made comments that have helped to improve this paper. This work was funded by a joint grant (NSC90-2911-I001-010 and NSC91-2911-I-001-001) from the National Science Council of the ROC and the Royal Society of London.

\section{References}

[1] C.S. Horng, M. Torii, K.S. Shea, S.J. Kao, Inconsistent magnetic polarities between greigite- and pyrrhotite/magnetite-bearing marine sediments from the Tsailiao-chi section, southwestern Taiwan, Earth Planet. Sci. Lett. 164 (1998) 467-481.

[2] W. O'Reilly, V. Hoffman, A.C. Chouker, H.C. Soffel, A. Menyeh, Magnetic properties of synthetic analogues of pyrrhotite ore in the grain size range 1-24 $\mu \mathrm{m}$, Geophys. J. Int. 142 (2000) 669-683.

[3] A.J. Hall, Pyrite-pyrrhotine redox reactions in nature, Mineral. Mag. 50 (1986) 223-229.

[4] M. Urbat, M.J. Dekkers, K. Krumsiek, Discharge of hydrothermal fluids through sediment at the Escanaba Trough, Gorda Ridge (ODP Leg 169): assessing the effects on the rock magnetic signal, Earth Planet. Sci. Lett. 176 (2000) 481-494.

[5] P. Rochette, J.P. Lorand, G. Fillion, V. Sautter, Pyrrhotite and the remanent magnetization of SNC meteorites: a changing perspective on Martian magnetism, Earth Planet. Sci. Lett. 190 (2001) $1-12$.

[6] P. Rochette, Metamorphic control of the magnetic mineralogy of black shales in the Swiss Alps: toward the use of "magnetic isogrades", Earth Planet. Sci. Lett. 84 (1987) 446-456.

[7] W. Bosum, U. Casten, F.C. Fieberg, I. Heyde, H.C. Soffel, Joint 3D interpretation of the KTB gravity and magnetic anomalies, J. Geophys. Res. 102 (1997) 18307-18321.

[8] C. Crouzet, P. Gautam, E. Schill, E. Appel, Multicomponent magnetization in western Dolpo (Tethyan Himalaya, Nepal): tectonic implications, Tectonophysics 377 (2003) 179-196.

[9] R.M. Garrels, C.L. Christ, Solutions, Minerals and Equilibria, Harper and Row, New York, 1965, 450 pp.

[10] M.A.A. Schoonen, H.L. Barnes, Mechanisms of pyrite and marcasite formation from solution: III. Hydrothermal processes, Geochim. Cosmochim. Acta 55 (1991) 3491-3504.

[11] A.R. Lennie, K.E.R. England, D.J. Vaughan, Transformation of synthetic mackinawite to hexagonal pyrrhotite: a kinetic study, Am. Mineral. 80 (1995) 960-967.

[12] J.H. Linssen, Preliminary results of a study of 4 successive sedimentary geomagnetic reversal records from the Mediterra- 
nean (upper Thvera, lower and upper Sidufjall, and lower Nunivak), Phys. Earth Planet. Inter. 52 (1988) 207-231.

[13] J.H. Linssen, Properties of Pliocene sedimentary geomagnetic reversal records from the Mediterranean, Geologica Ultraiectina 80 (1991) $231 \mathrm{pp}$.

[14] X. Quidelleur, J.-P. Valet, N. Thouveny, Multicomponent magnetization in paleomagnetic records of reversals from continental sediments in Bolivia, Earth Planet. Sci. Lett. 111 (1992) 23-39.

[15] A.J. van Velzen, M.J. Dekkers, J.D.A. Zijderveld, Magnetic iron-nickel sulphides in the Pliocene and Pleistocene marine marls from the Vrica section (Calabria, Italy), Earth Planet. Sci. Lett. 115 (1993) $43-55$.

[16] A.P. Roberts, G.M. Turner, Diagenetic formation of ferrimagnetic iron sulphide minerals in rapidly deposited marine sediments, South Island, New Zealand, Earth Planet. Sci. Lett. 115 (1993) 257-273.

[17] C. Mary, S. Iaccarino, V. Courtillot, J. Besse, D.M. Aïssaoui, Magnetostratigraphy of Pliocene sediments from the Stirone River (Po Valley), Geophys. J. Int. 112 (1993) 359-380.

[18] L. Sagnotti, P. Macri, A. Camerlenghi, M. Rebesco, Environmental magnetism of Antarctic Late Pleistocene sediments and interhemispheric correlation of climatic events, Earth Planet. Sci. Lett. 192 (2001) 65-80.

[19] J.E.T. Channell, J.S. Stoner, Plio-Pleistocene magnetic polarity stratigraphies and diagenetic magnetite dissolution at ODP Leg 177 Sites (1089, 1091, 1093 and 1094), Mar. Micropal. 45 (2002) 269-290.

[20] J.S. Stoner, J.E.T. Channell, D.A. Hodell, C.D. Charles, A similar to $580 \mathrm{kyr}$ paleomagnetic record from the sub-Antarctic South Atlantic (Ocean Drilling Program Site 1089), J. Geophys. Res. 108 (B5) (2003), doi:10.1029/2001JB001390 (art. no. 2244).

[21] I. Vasiliev, W. Krijgsman, C.G. Langereis, C.E. Panaiotu, L. Matenco, G. Bertotti, Towards an astrochronological framework for the eastern Paratethys Mio-Pliocene sedimentary sequences of the Focsani basin (Romania), Earth Planet. Sci. Lett. 227 (2004) 231-247.

[22] C.S. Horng, J.C. Chen, T.Q. Lee, Variations in magnetic minerals from two Plio-Pleistocene marine-deposited sections, southwestern Taiwan, J. Geol. Soc. China 35 (1992) 323-335.

[23] C.S. Horng, C. Laj, T.Q. Lee, J.C. Chen, Magnetic characteristics of sedimentary rocks from the Tsengwen-chi and Erhjenchi sections in southwestern Taiwan, TAO 3 (1992) 519-532.

[24] W.T. Jiang, C.S. Horng, A.P. Roberts, D.R. Peacor, Contradictory magnetic polarities in sediments and variable timing of neoformation of authigenic greigite, Earth Planet. Sci. Lett. 193 (2001) $1-12$.

[25] C.S. Ho, Tectonic Evolution of Taiwan: explanatory text of the tectonic map of Taiwan, Ministry of Economic Affairs, Taiwan, 1982, 126 pp.

[26] H.S. Yu, An under-filled foreland basin in the northern South China Sea off southwest Taiwan: incipient collision and foreland sedimentation, in: P. Clift, et al., (Eds.), Continent-Ocean Interactions within East Asian Marginal Seas, AGU Geophys. Monogr. Ser., vol. 149, 2004, pp. 159-173.

[27] S.J. Kao, C.S. Horng, A.P. Roberts, K.K. Liu, Carbon-sulfuriron relationships in sedimentary rocks from southwestern Taiwan: influence of geochemical environment on greigite and pyrrhotite formation, Chem. Geol. 203 (2004) 153-168.

[28] C.H. Chen, C.H. Wang, Explanatory Notes for the Metamorphic Facies Map of Taiwan, 2nd ed., Central Geological Survey, Taiwan, 1995, (in Chinese) 48 pp.
[29] M.J. Dekkers, Magnetic properties of natural pyrrhotite. II. High- and low-temperature behaviour of Jrs and TRM as function of grain size, Phys. Earth Planet. Inter. 57 (1989) 266-283.

[30] R. Weaver, A.P. Roberts, A.J. Barker, A late diagenetic (synfolding) magnetization carried by pyrrhotite: implications for paleomagnetic studies from magnetic iron sulphide-bearing sediments, Earth Planet. Sci. Lett. 200 (2002) 371-386.

[31] A.P. Roberts, R. Weaver, Multiple mechanisms of remagnetization involving sedimentary greigite $\left(\mathrm{Fe}_{3} \mathrm{~S}_{4}\right)$, Earth Planet. Sci. Lett. 231 (2005) 263-277.

[32] D.J. Vaughan, J.R. Craig, Mineral Chemistry of Metal Sulfides, Cambridge University Press, Cambridge, 1978, 493 pp.

[33] D. Jordanova, V. Hoffman, K.T. Fehr, Mineral magnetic characterization of anthropogenic magnetic phases in the Danube river sediments (Bulgarian part), Earth Planet. Sci. Lett. 221 (2004) 71-89.

[34] Y.H. Li, Denudation of Taiwan island since the Pliocene epoch, Geology 4 (1976) 105-107.

[35] C.F. You, T. Lee, L. Brown, J.J. Shen, J.C. Chen, ${ }^{10}$ Be study of rapid erosion in Taiwan, Geochim. Cosmochim. Acta 52 (1988) 2687-2691.

[36] W.A. Deer, R.A. Howie, J. Zussman, An Introduction to the Rock Forming Minerals, 2nd ed., Prentice Hall, London, 1996, 696 pp.

[37] R.E. Sweeney, I.R. Kaplan, Pyrite framboid formation: laboratory synthesis and marine sediments, Econ. Geol. 68 (1973) 618-634.

[38] D. Rickard, M.A.A. Schoonen, G.W. Luther III, Chemistry of iron sulfides in sedimentary environments, in: V. Vairavamurthy, M.A.A. Schoonen (Eds.), Geochemical Transformations of Sedimentary Sulfur, American Chemical Society Symposium Series, vol. 612, 1995, pp. 168-193.

[39] M.L. Tuttle, M.B. Goldhaber, Sedimentary sulfur geochemistry of the Paleogene Green River Formation, western USA: implications for interpreting depositional and diagenetic processes in saline alkaline lakes, Geochim. Cosmochim. Acta 57 (1993) 3023-3039.

[40] M. Jackson, P. Rochette, G. Fillion, S. Banerjee, J. Marvin, Rock magnetism of remagnetized Paleozoic carbonates: low-temperature behavior and susceptibility characteristics, J. Geophys. Res. 98 (1993) 6217-6225.

[41] W. Xu, R. Van der Voo, D. Peacor, Electron microscopic and rock magnetic study of remagnetized Leadville carbonates, central Colorado, Tectonophysics 296 (1998) 333-362.

[42] J. Dinarès-Turell, M.J. Dekkers, Diagenesis and remanence acquisition in the Lower Pliocene Trubi marls at Punta di Maiata (southern Sicily): palaeomagnetic and rock magnetic observations, in: D.H. Tarling, P. Turner (Eds.), Palaeomagnetism and Diagenesis in Sediments, Geol. Soc. London Spec. Publ., vol. 151, 1999, pp. 53-69.

[43] Y. Otofuji, K. Takemoto, H. Zaman, Y. Nishimitsu, Y. Wada, Cenozoic remagnetization of the Paleozoic rocks in the Kitakami massif of northeast Japan, and its tectonic implications, Earth Planet. Sci. Lett. 210 (2003) 203-217.

[44] T.E. Zegers, M.J. Dekkers, S. Bailly, Late Carboniferous to Permian remagnetization of Devonian limestones in the Ardennes: role of temperature, fluids, and deformation, J. Geophys. Res. 108 (B7) (2003), doi:10.1029/2002JB002213 (art. no. 2357).

[45] M.J. Dekkers, J.-L. Mattéi, G. Fillion, P. Rochette, Grain-size dependence of the magnetic behavior of pyrrhotite during its low-temperature transition at $34 \mathrm{~K}$, Geophys. Res. Lett. 16 (1989) 855-858. 
[46] P. Rochette, G. Fillion, J.-L. Mattéi, M.J. Dekkers, Magnetic transition at 30-34 Kelvin in pyrrhotite: insight into a widespread occurrence of this mineral in rocks, Earth Planet. Sci. Lett. 98 (1990) 319-328.

[47] M.J. Dekkers, Magnetic properties of natural pyrrhotite. I. Behaviour of initial susceptibility and saturation-magnetizationrelated rock-magnetic parameters in a grain-size dependent framework, Phys. Earth Planet. Inter. 52 (1988) 376-393.

[48] A.P. Roberts, Magnetic properties of sedimentary greigite $\left(\mathrm{Fe}_{3} \mathrm{~S}_{4}\right)$, Earth Planet. Sci. Lett. 134 (1995) 227-236.

[49] W. Lowrie, Identification of ferromagnetic minerals in a rock by coercivity and unblocking temperature properties, Geophys. Res. Lett. 17 (1990) 159-162.

[50] B.A. Housen, S.K. Banerjee, B.M. Moskowitz, Low-temperature magnetic properties of siderite and magnetite in marine sediments, Geophys. Res. Lett. 23 (1996) 2843-2846.

[51] B.M. Moskowitz, M. Jackson, C. Kissel, Low-temperature magnetic behavior of titanomagnetites, Earth Planet. Sci. Lett. 157 (1998) 141-149.

[52] Ö. Özdemir, D.J. Dunlop, Low-temperature behavior and memory of iron-rich titanomagnetites (Mt. Haruna, Japan and Mt. Pinatubo, Philippines), Earth Planet. Sci. Lett. 216 (2003) 193-200.
[53] M. Torii, K. Fukuma, C.S. Horng, T.Q. Lee, Magnetic discrimination of pyrrhotite- and greigite-bearing sediment samples, Geophys. Res. Lett. 23 (1996) 1813-1816.

[54] R.H. Carpenter, Pyrrhotite isograd in southeastern Tennessee and southwestern North Carolina, Geol. Soc. Am. Bull. 85 (1974) 451-456.

[55] J.M. Ferry, Petrology of graphitic sulfide-rich schists from south-central Maine: an example of desulfidation during prograde regional metamorphism, Am. Mineral. 66 (1981) $908-931$.

[56] D.W. Mohr, R.C. Newton, Kyanite-staurolite metamorphism in sulfidic schists of the Anakeesta Formation, Great Smoky Mountains, North Carolina, Am. J. Sci. 283 (1983) 97-134.

[57] S.L. Gillett, Paleomagnetism of the Notch Peak contact metamorphic aureole, revisited: pyrrhotite from magnetite + pyrite under submetamorphic conditions, J. Geophys. Res. 108 (B9) (2003), doi:10.1029/2002JB002386 (art. no. 2446).

[58] M. Posfai, T.G. Sharp, A. Kontny, Pyrrhotite varieties from the $9.1 \mathrm{~km}$ deep borehole of the KTB project, Am. Mineral. 85 (2000) 1406-1415.

[59] C.D. Shi, R.X. Zhu, V. Suchy, A. Zeman, B. Guo, Y.X. Pan, Identification and origins of iron sulfides in Czech loess, Geophys. Res. Lett. 28 (2001) 3903-3906. 